\title{
Effect of Replacing Maize (Zea Mays L.) with Orange Fleshed Sweet Potato Tuber (Ipomoea Batatas) on Performance of Cobb 500 Broiler Chickens
}

\author{
Mosebework Kassa ${ }^{1}$, Tegene Negesse ${ }^{2 *}$ and Ajebu Nurfeta ${ }^{1}$ \\ ${ }^{1}$ Worabe University, Ethiopia \\ ${ }^{2}$ Hawassa University, College of Agriculture, Ethiopia \\ Submission: December 12, 2017; Published: February 01, 2018 \\ "Corresponding author: Tegene Negesse, Hawassa University, College of Agriculture and Range Sciences Hawassa, Ethiopia, \\ Email: tegenengss38@gmail.com
}

\begin{abstract}
Effect of replacing maize with cooked orange flesh sweet potato tuber on feed intake, body weight gain (BWG), carcass characteristics and feed conversion efficiency (DMCR) of Cobb 500 broiler chicks and profitability of the rations was evaluated in Hawassa University, in 2017. Sexed 150 Cobb 500 broiler chicks were randomly assigned to 5 treatments (T1...T5) each with 3 replications in a completely randomized design. T1 contained 0\% partially cooked sweet potato tuber meal (PCSPTM), T2 4\% CSPT, T3 8\% PCSPTM, T4 12\%CSPT and T516\% CSPT during starter phase and $0 \%, 5 \%, 10 \%, 15 \%$ and 20\% PCSPTM in T1.....T5,respectivelyduring growth phase as percent of concentrate mix. Intake of DM during the starter phase, grower phase and the entire trial period was higher $(\mathrm{P}<0.05)$ for $\mathrm{T} 4$ and $\mathrm{T} 5$ compared with $\mathrm{T} 1, \mathrm{~T} 2$ and $\mathrm{T} 3$. The highest $(\mathrm{P}<0.05)$ (BWG) was recorded in broilers fed T3 during starter phase while the highest BWG was recorded in T4 and T5 during grower phase and the entire experimental period. DMCR of $\mathrm{T} 5$ was better $(\mathrm{P}<0.05)$ than that of the other treatments during starter phase, but during grower and entire period T2 had the highest $(\mathrm{P}<0.05)$ of all treatments. The carcass weight of the chick fed T5 and T4 was significantly higher than that of T1 and T2 but it was similar $(P>0.05)$ with those fed $T 3$. There was no significant difference $(P>0.05)$ in dressing percentage between treatments. The highest total return, net income and marginal rate of return was noted for T5. It can be conclude that PCSPTM can be fed to broiler chickens up to $16 \%$ of diet during starter and up to $20 \%$ during grower phase with promising growth performance.
\end{abstract}

Keywords: Broiler; Partial cooked; Performance; Sweet potato

Abbreviations: BWG: Body Weight Gain; PCSPTM: Partially Cooked Sweet Potato Tuber Meal

\section{Introduction}

Ethiopia is one of the few African countries with a large population of chicken which covers $60 \%$ of the population [1]. Poultry plays an important economic, nutritional and socio-cultural role in the livelihood of rural households in many developing countries, including Ethiopia. Many scholars are of the opinion that developing the poultry industry in the developing nations can be the fastest means of bridging the existing gap in protein deficiency [2,3]. The scarcity and prohibitive cost of commercial energy sources like maize and sorghum for poultry rations, has been the main cause of the high cost of poultry products especially in developing countries. This will subsequently lead to inhibition of the cost of production of poultry meat. According to the production data base [4], the total number of chickens for meat production in the world was 59.7 billion in 2012. Maize serves as the major energy ingredient in the diets of most livestock and especially non-ruminants like poultry. A decrease in the availability of maize and an increase in the price for feed have a direct impact on the broiler industry worldwide [5].In order to step down the problem of high and unstable price situation and save the collapse of the poultry industry, there is the need to broaden the energy source base by assessing unconventional feedstuffs [6]. In order to compensate for this change, alternative feed ingredients must be identified [7]. The new ingredients must be able to substitute for maize totally or partially and not have a negative impact on the efficiency of broilers [8].

The other type of feed which could be used for poultry is sweet potato which is capable of thriving and yielding well on poor soils and may be a saving grace for the poultry industry [9]. The rising costs of maize necessitate a research for cheaper and locally available non-conventional energy feed stuffs such as sweet potato (Ipomoea batatas LAM). It is for this reason that sweet potato which at present has limited alternative uses, cheap and has a stable price compared to cereal crops, 
is being considered for evaluation in the feeding of broiler chickens. Non-conventional feedstuffs offer the best alternative for the reduction of feed cost and cost of animal products [9]. Sweet potato is a tuber crop produced in most countries and is consumed mainly as a starch source in the diet of humans but is also rich in other important nutrients [10]. Over 95\% of sweet potato is produced in developing countries [11].

The storage tubers of sweet potato are valuable source of carbohydrates, vitamins, and micro-nutrients especially in the orange and yellow-fleshed cultivars, which contain $\beta$-carotene. But sweet potato tubers are very low in fiber content.The digestibility of sweet potato carbohydrate fraction is reported to be above $90 \%$ [12]. Some studies have indicated that sweet potato can replace maize in the diet of broilers [13]. Sweet potato tubers contain different anti-nutritional factors which reduce dry matter digestibility and Metabolizable protein and, energy values even when rations contained adequate and high quality proteins [14]. Preheating can destroy or reduce these trypsin inhibitors. Earlier result show that when sweet potato tuber is cooked, between $17 \%$ and $31 \%$ trypsin inhibit or activity remained and when it was prepared into flour only $5-12 \%$ trypsin inhibit or activity was found.

This study was designed to evaluate the effect of replacing maize with cooked orange-fleshed sweet potato tuber meal/ flour on feed intake, body weight gain and carcass characteristics of broiler chicken.

\section{Materials and Methods}

\section{Description of study area}

The experiment was conducted at College of Agriculture, Hawassa University which is situated $265 \mathrm{~km}$ south of Addis Ababa at $7^{\circ} 4^{\prime} \mathrm{N}$ latitude and $38^{\circ} 31^{\prime} \mathrm{E}$ longitude at an altitude of 1680 meter above sea level. The main rainy season extends from April to September interrupted by some dry spells in May or June with annual precipitation ranging between 1000 and $1200 \mathrm{~mm}$. The mean minimum and maximum temperatures in the study area are $13.5^{\circ} \mathrm{C}$ and $27.6^{\circ} \mathrm{C}[15]$.

\section{Collecting and processing of sweet potato tuber}

The orange fleshed sweet potato tuber was collected from Tula Grarekata farm, district of Sidama zone (southern Ethiopia). The tubers were thoroughly washed, sorted, peeled and sliced into equal sized chips using a knife to facilitate uniformity in cooking. Sweet potato tuber was partially cooked in boiled water at $100{ }^{\circ} \mathrm{C}$ for forty five minutes to eliminate trypsin inhibit or activity [12]. The chopped sweet potato was air dried on concrete floor for one week to a moisture content of less than $10 \%$ to reduce enzymatic and microbial reactions which may lead to spoilage. Finally air dried sweet potato was groundand used in feed preparation.

\section{Preparation of experimental house}

The experimental broiler house was divided by wire mesh into 15 equal sized pens. Each pen was separated by $2 \mathrm{~m} \times 2 \mathrm{~m}$ and properly washed and cleaned by using tap water and disinfected by Iosan. Pen floors were covered with saw dust to $5 \mathrm{~cm}$ depth.

\section{Experimental chicks and their management}

Day-old broilers $(46+1 \mathrm{~g})$ were bought from Alema farm, Debre-Zeyit. The birds received constant illumination and had free access to water and feed. Heat was provided in the daytime by using 150 watt infra-red light bulbs placed in strategic points in the brooder. Moreover, heat from burnt charcoal was used together with bulbs to provide heat during cool nights. During the adaptation period fresh clean drinking water mixed with multivitamins was also given ad libitum for the chicks to overcome stress according to the manufacturer's recommendation.

The chicks were vaccinated against Newcastle disease, infectious BD and Lasota disease at 7, 14 and 21 days of age, respectively, according to the manufacturer's guideline. After brooding the chicks were weighed individually to determine initial body weights. They were weighed and transferred to the pens in a separate house. The pens were properly ventilated and electrically heated using two 60 watt light bulbs per pen. The wet litter was changed with dry and clean sawdust whenever necessary. The litter material used was occasionally turned and was totally changed to prevent any contamination during the grower phase. The chicks were offered their respective diets twice a day at 8:00 and 16:00 hours. The refusals were measured every morning using sensitive balance for calculation of feed consumption.

\section{Experiment lay out}

At seven days of age $(98 \pm 2.5 \mathrm{~g}$ body weight), the chicks were distributed in a completely randomized design (CRD) consisting of 5 dietary treatments replicated 3 times, with 10 birds per replicate. The control diet (Table 1) contain maize as the major energy source with no sweet potato tuber meal and other diets (Table 2-5) contained different levels of PCSPTM to partially replace maize in the control diet.

\section{Experimental Diets and Ingredients}

The feed ingredients used in the formulation of the different experimental rations of this study were maize(Zea mays), roasted soybean seed (Glysine max), wheat bran, noug seed cake (Guizotia abyssinica), PCSPTM, premix, limestone and salt (Table $1 \& 2$ ).Chicks were fed starter and grower diets for 21 days during each phase. Based on NRC [16] recommendation for optimum production $3200 \mathrm{kcal} / \mathrm{kg}$ DM metabolizable energy (ME) is adequate for growing broilers and rations must contain $23 \%$ and $20 \%$ of crude protein, for broiler starter and grower, respectively. 


\section{Agricultural Research \& Technology: Open Access Journal}

Table1: Proportion of feed ingredients (\%) of starter diets fed to broiler chickens.

\begin{tabular}{|c|c|c|c|c|c|c|}
\hline \multirow{2}{*}{ Ingredient (\%) } & \multicolumn{6}{|c|}{ Treatment Diets } \\
\hline & Week 1 & T1 & T2 & T3 & T4 & T5 \\
\hline Maize & 40 & 40 & 36 & 32 & 28 & 24 \\
\hline $\begin{array}{l}\text { Sweet potato tuber (dried and } \\
\text { ground) }\end{array}$ & 1.5 & 0 & 4 & 8 & 12 & 16 \\
\hline Wheat bran & 11 & 12 & 12 & 12 & 12 & 12 \\
\hline Noug cake & 6 & 6 & 6 & 6 & 6 & 6 \\
\hline Roasted soybean & 40 & 40 & 40 & 40 & 40 & 40 \\
\hline Limestone & 0.5 & 0.5 & 0.5 & 0.5 & 0.5 & 0.5 \\
\hline Salt & 0.5 & 0.5 & 0.5 & 0.5 & 0.5 & 0.5 \\
\hline Premix/mineral \&vitamin & 0.5 & 1 & 1 & 1 & 1 & 1 \\
\hline Total & 100 & 100 & 100 & 100 & 100 & 100 \\
\hline \multicolumn{7}{|c|}{ Nutrient composition } \\
\hline Crude protein (\% DM) & 23.47 & 22.37 & 22.2 & $22 . .03$ & 21.86 & 21.8 \\
\hline Crude fiber (\% DM) & 6.03 & 6.2 & 6.2 & 6.1 & 6.2 & 6.2 \\
\hline Metabolizable energy (kcal/kg DM) & 3270 & 3278 & 3249 & 3250 & 3251 & 3252 \\
\hline
\end{tabular}

Grower phase (4-6 week): 3-week old broiler chickens acquired from the starter phase were used. The treatments diets consisted of: T1= ration containing $\%$ PCSPTM $+50 \%$ Maize; T2=ration containing 5\% PCSPTM +45\% Maize; T3=ration containing $10 \%$ PCSPTM + 40\% Maize T4=ration containing 15\% PCSPTM + 35\% Maize and T5=ration containing 20\% PCSPTM + 30\% Maize. Similar data like that of starter phase were collected during the grower phase as well.

Table 2: Proportion of feed ingredients (\%) of grower diets fed to broiler chickens.

\begin{tabular}{|c|c|c|c|c|c|}
\hline \multirow{2}{*}{ Ingredient (\%) } & \multicolumn{5}{|c|}{ Treatment } \\
\hline & T1 & T2 & T3 & T4 & T5 \\
\hline Maize & 50 & 45 & 40 & 35 & 30 \\
\hline $\begin{array}{l}\text { Sweet potato tuber } \\
\text { (dried and ground) }\end{array}$ & 0 & 5 & 10 & 15 & 20 \\
\hline Wheat bran & 12 & 12 & 12 & 12 & 12 \\
\hline Noug cake & 6 & 6 & 6 & 6 & 6 \\
\hline Roasted soybean & 30 & 30 & 30 & 30 & 30 \\
\hline Limestone & 0.5 & 0.5 & 0.5 & 0.5 & 0.5 \\
\hline Salt & 0.5 & 0.5 & 0.5 & 0.5 & 0.5 \\
\hline $\begin{array}{c}\text { Premix/mineral \& } \\
\text { vitamin }\end{array}$ & 1 & 1 & 1 & 1 & 1 \\
\hline Total & 100 & 100 & 100 & 100 & 100 \\
\hline \multicolumn{6}{|c|}{ Nutrient composition } \\
\hline Crud Protein (\%DM) & 19.3 & 19 & 18.56 & 18.36 & 18.14 \\
\hline Crude Fiber (\%DM) & 5.73 & 5.72 & 5.73 & 5.72 & 5.73 \\
\hline $\begin{array}{l}\text { Metabolizable Energy } \\
\text { (kcal/kg DM) }\end{array}$ & 3278 & 3249 & 3250 & 3251 & 3252 \\
\hline
\end{tabular}

\section{Starter phase (1-3 week)}

The experimental diets that were fed after adaptation period were

a. T1=ration containing $0 \%$ PCSPTM+40\% Maize;

b. $\quad \mathrm{T} 2=$ ration containing $4 \%$ PCSPTM $+36 \%$ Maize;

c. $\quad$ T3=ration containing 8\% PCSPTM $+32 \%$ Maize;

d. T4=ration containing $12 \%$ PCSPTM + 28\% Maize and

e. T5=ration containing 16\% PCSPTM $+24 \%$ Maize.
Records of feed offered and refused, body weight, and mortality were kept for each replicate in a treatment group.

\section{Grower phase (4-6 week)}

3-week old broiler chickens acquired from the starter phase were used. The treatments diets consisted of

a. $\quad \mathrm{T} 1=$ ration containing $0 \% \mathrm{PCSPTM}+50 \%$ Maize;

b. $\quad$ T2=ration containing 5\% PCSPTM +45\% Maize;

c. $\quad \mathrm{T} 3=$ ration containing $10 \%$ PCSPTM $+40 \%$ Maize; 
d. T4=ration containing 15\% PCSPTM $+35 \%$ Maize and

e. T5=ration containing 20\% PCSPTM + 30\% Maize. Similar data like that of starter phase were collected during the grower phase as well.

\section{Body Weight and Carcass Measurements}

Birds in a replicate were weighed together throughout the experimental period at weekly intervals and average weight of chicks calculated. Feed conversion ratio was calculated by dividing feed intake by weight gain. At the end of the experiment 9 birds per treatment (3 per replicate) were selected to determine carcass characteristics. Feed was withdrawn for 12 hours in preparation for slaughter, and the fast body weight of each bird was taken and recorded. The feathers were removed. After dressing, the weights of dressed carcass, edible and nonedible carcass were determined according to the procedure of Zanu et al. [17]. Thus, the total edible meat was the sum of carcass weight and edible organs. The dressing percentage was determined by dividing total edible meat by slaughter live weight and multiplied by 100 .

\section{Chemical Analysis}

This was carried out at Hawassa University College of Agriculture Animal Nutrition laboratory and soil laboratory. Samples were analyzed for dry matter (DM), crude protein (CP), ether extract (EE), crude fiber (CF), Ash, Ca and P using the Weende or proximate analysis method [18]. Kjeldhal procedure [18] of nitrogen analysis was used to determine nitrogen $(\mathrm{N})$ and the crude protein (CP) was calculated as N x 6.25.Mineral (Ca and P) was analyzed by atomic absorption spectrometer [18]. All the laboratory analyses were carried out in duplicate. Metabolizable energy (ME) of the rations was estimated as follows ME (kcal/ kg $\mathrm{DM})=3951+54.4 \mathrm{EE}-88.7 \mathrm{CF}-40.8$ ash [19].

\section{Partial Budget Analysis}

For the determination of the potential profitability of PCSPTM by partial budget analysis, purchasing and selling prices of chick and the total quantity of basal and supplement feed and its purchasing prices were recorded where as veterinary services were common for all treatments.

\section{Statistical Analysis}

Data were analyzed for ANOVA using Statistical Analysis System (SAS, 2009 version 9.0) and means were separated using Tukey test at $5 \%$ of significance level. The model used was Yij= $\mu+\mathrm{ti}+\mathrm{eij}$, where; $\mathrm{Yij}=$ the response variable; $\mu=$ overall mean; $\mathrm{ti}=$ treatment effect and eij= random error.

\section{Results}

\section{Chemical composition of ingredients and experimental rations}

The CP (6.56\%), CF (1.97\%), EE (1.05\%) and P (0.2) contents of partially cooked orange flesh sweet potato tuber was lower than that of maize $(8.47,3.8,3.02$ and $0.25 \%$, respectively) and other ingredients, but its ash (3.91\%) and calcium $(0.3 \%)$ contents were higher than that of maize (2.44 and $0.1 \%$, respectively). The ME content of PCSPTM (3674 kcal ME/kg) was slightly lower than that of maize (3678 kcal ME/kg).

The $\mathrm{CF}$ and EE content of starter and grower diets in the present study slightly decreased with increasing level of CSPTM. The calcium content of the diet increased as the level of PCSPTM increased (Table 3).

Table 3: Chemical composition (\%DM unless specified) of the starter and grower rations.

\begin{tabular}{|c|c|c|c|c|c|c|c|c|c|c|}
\hline \multirow{2}{*}{ Feed composition } & \multicolumn{5}{|c|}{ Starter phase } & \multicolumn{5}{|c|}{ Grower phase } \\
\hline & T1 & T2 & T3 & T4 & T5 & T1 & T2 & T3 & T4 & T5 \\
\hline DM (\%) & 95.4 & 95.65 & 96.23 & 97.29 & 96 & 95.87 & 95.68 & 95.61 & 96.9 & 95.57 \\
\hline Ash & 5.81 & 4.86 & 4.44 & 4.22 & 4.4 & 5.14 & 5.05 & 5.25 & 5.02 & 4.28 \\
\hline Ether extract & 4.2 & 4.04 & 4.1 & 3.7 & 3.4 & 4.8 & 4.5 & 4.03 & 3.99 & 3.5 \\
\hline Crude fiber & 8.5 & 8.2 & 7.96 & 7.7 & 7.4 & 8.3 & 8.04 & 7.6 & 7.54 & 7.52 \\
\hline Crude protein & 23.1 & 23.31 & 23.48 & 23.37 & 23 & 20.38 & 20.4 & 20.24 & 20.8 & 20.25 \\
\hline Calcium & 0.9 & 0.98 & 1.2 & 1.3 & 1.7 & 1 & 1.1 & 1.44 & 1.3 & 1.34 \\
\hline Phosphorus & 0.32 & 0.25 & 0.4 & 0.33 & 0.3 & 0.41 & 0.36 & 0.39 & 0.35 & 0.29 \\
\hline ME (kcal/kg) & 3188 & 3245 & 3287 & 3297 & 3298.2 & 3266 & 3277 & 3282 & 3294 & 3300 \\
\hline
\end{tabular}

\section{Dry matter and nutrient intake}

The dry matter (DM) and nutrient intake during the starter and grower phases are presented in (Table 4). Total DM intake during the starter, grower and entire experimental period were higher $(\mathrm{P}<0.05)$ for groups fed T4 and T5 diets than those fed with the other treatments, the difference being more pronounced during the last three weeks of the grower phase (Figure 1). The average daily $\mathrm{CP}$ intake during the starter phase in $\mathrm{T} 1$ and $\mathrm{T} 2$ was higher $(\mathrm{P}<0.05)$ than in $\mathrm{T} 5$ but it was similar $(\mathrm{P}>0.05)$ with $\mathrm{T} 3$ and T4. During the grower phase, the CP intake for T1 and T2 was greater than that of $\mathrm{T} 3$, with similar $(\mathrm{P}>0.05)$ intake with $\mathrm{T} 4$ and T5. The mean daily ME intakes during starter and grower phase did not differ $(\mathrm{P}>0.05)$ significantly among the five dietary treatments. 


\section{Agricultural Research \& Technology: Open Access Journal}

Table 4: Effect of replacing cooked orange fleshed sweet potato tuber meal with maize meal on dry matter and nutrient intakes of broilers during starter and grower phases.

\begin{tabular}{|c|c|c|c|c|c|c|c|}
\hline \multirow[b]{2}{*}{ Intake } & \multicolumn{7}{|c|}{ Treatment Diets } \\
\hline & T1 & T2 & T3 & T4 & T5 & SEM & SL \\
\hline \multicolumn{8}{|c|}{ Starter phase } \\
\hline Total dry matter (g/bird) & $851^{\mathrm{b}}$ & $853^{\mathrm{b}}$ & $857^{\mathrm{b}}$ & $902^{\mathrm{a}}$ & $908^{\mathrm{a}}$ & 3.06 & $*$ \\
\hline Dry matter (g/bird/day) & $41^{\mathrm{b}}$ & $41^{\mathrm{b}}$ & $41^{\mathrm{b}}$ & $43^{\mathrm{a}}$ & $43^{\mathrm{a}}$ & 0.15 & * \\
\hline ME(kcal/bird/day) & 223 & 223 & 223 & 223 & 223 & 0.1 & Ns \\
\hline Crude protein(g/bird/day) & $10.9^{\mathrm{a}}$ & $10.7^{\mathrm{ab}}$ & $9.9^{\mathrm{ab}}$ & $9.3^{\mathrm{ab}}$ & $9.1^{\mathrm{b}}$ & 0.5 & $*$ \\
\hline \multicolumn{8}{|c|}{ Grower phase } \\
\hline Total DM (g/bird) & $1900^{c}$ & $1958^{c}$ & $2052^{\mathrm{b}}$ & $2175^{\mathrm{a}}$ & $2192^{\mathrm{a}}$ & 18.3 & * \\
\hline Dry matter (g/bird/day) & $91^{\mathrm{c}}$ & $93^{\mathrm{c}}$ & $98^{\mathrm{b}}$ & $104^{\mathrm{a}}$ & $104^{\mathrm{a}}$ & 0.87 & $*$ \\
\hline ME (kcal/bird/day) & 394 & 401 & 394 & 402 & 401 & 10 & Ns \\
\hline Crude protein (g/bird/day) & $23.9^{\mathrm{a}}$ & $23.7^{\mathrm{a}}$ & $20.0^{\mathrm{b}}$ & $21.8^{\mathrm{ab}}$ & $21.7^{\mathrm{ab}}$ & 0.6 & * \\
\hline \multicolumn{8}{|c|}{ Entire period } \\
\hline Dry matter (g/bird) & $2751^{\mathrm{c}}$ & $2811^{c}$ & $2910^{\mathrm{b}}$ & $3076^{\mathrm{a}}$ & $3100^{\mathrm{a}}$ & 18.1 & * \\
\hline Dry matter (g/bird/day) & $66^{c}$ & $67^{c}$ & $69^{\mathrm{b}}$ & $73^{\mathrm{a}}$ & $74^{\mathrm{a}}$ & 0.43 & $*$ \\
\hline
\end{tabular}

abcmeans within the same row bearing different superscripts are significantly different $(P<0.05)$; $S E M=$ significant error of mean; $S L=$ significant level; ns= non- significant; ${ }^{*}=$ significant at $5 \%$.

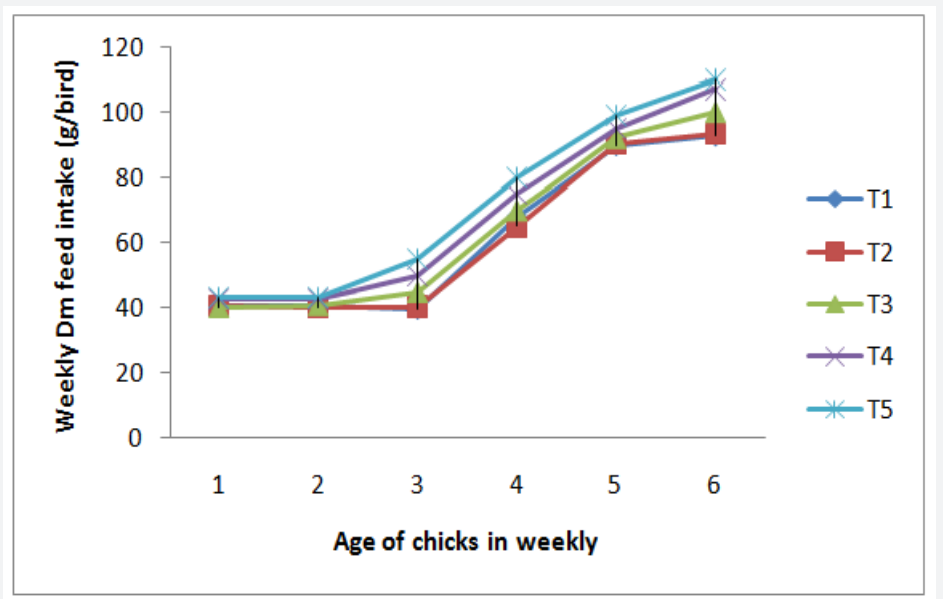

Figure 1: The weekly dry matter intake of chicks during the experimental period.

\section{Body Weight Gain and Dry Matter Conversion Ratio}

The initial body weights of chicks were similar. The body weight gain $(\mathrm{BWG})$ for $\mathrm{T} 3$ was higher $(\mathrm{P}<0.05)$ than that of $\mathrm{T} 4$, T5 and $\mathrm{T} 1$ but it was similar with $\mathrm{T} 2$ during the starter phase (Table 5). During the grower phase the BWG for $\mathrm{T} 5$ was greater $(\mathrm{P}<0.05)$ than that of T1 and T2. However, for the entire experimental period BWG for $\mathrm{T} 3, \mathrm{~T} 4$ and $\mathrm{T} 5$ was higher $(\mathrm{P}<0.05)$ than that of $\mathrm{T} 1$ and $\mathrm{T} 2$. Birds fed T5 ration had the highest $(\mathrm{P}<0.05)$ dry matter conversion ratio (DMCR) during the starter phase. During the grower phase and the entire experimental period, the groups consuming $\mathrm{T} 2$ diets had the highest $(\mathrm{P}<0.05) \mathrm{DMCR}$.

Birds continuously increased body weight up to week three in all treatment groups, but T3 gained at faster rate than the remaining treatments between the third and fourth week of the experiment. After week five T3, T4, and T5 had highest body weight than T1 and T2 (Figure 2). 


\section{Agricultural Research \& Technology: Open Access Journal}

Table 5: The Effect of substituting cooked orange fleshed sweet potato tuber meal for maize on body weight gain and feed conversion ratio of broiler's during the starter and grower phases.

\begin{tabular}{|c|c|c|c|c|c|c|c|}
\hline \multirow{2}{*}{ Body weight } & \multicolumn{7}{|c|}{ Treatment } \\
\hline & T1 & T2 & T3 & T4 & T5 & SEM & SL \\
\hline \multicolumn{8}{|c|}{ Starter phase } \\
\hline Initial body weight (g) & 97.8 & 99.6 & 97.6 & 98.2 & 99.2 & 0.38 & Ns \\
\hline Final body weight (g) & $512^{\mathrm{b}}$ & $600^{\text {ba }}$ & $659^{a}$ & $512^{\mathrm{b}}$ & $462^{\mathrm{b}}$ & 30 & * \\
\hline Total BWG (g/bird) & $414^{\mathrm{b}}$ & $500^{\text {ba }}$ & $561^{a}$ & $414^{\mathrm{b}}$ & $362^{\mathrm{b}}$ & 30 & $*$ \\
\hline ADG (g/bird) & $20^{\mathrm{b}}$ & $24^{\mathrm{ab}}$ & $27^{\mathrm{a}}$ & $20^{\mathrm{b}}$ & $17^{\mathrm{b}}$ & 1.4 & * \\
\hline \multicolumn{8}{|c|}{ Grower phase } \\
\hline Initial BW (g) & $512^{\mathrm{b}}$ & $600^{\mathrm{ab}}$ & $659^{\mathrm{a}}$ & $512^{\mathrm{b}}$ & $462^{\mathrm{b}}$ & 30 & * \\
\hline Final BW (g) & $1147^{b}$ & $1127^{b}$ & $1387^{\mathrm{a}}$ & $1417^{a}$ & $1413^{\mathrm{a}}$ & 36 & $*$ \\
\hline Total BWG (g/bird) & $635^{b}$ & $527^{\mathrm{b}}$ & $728^{\mathrm{ab}}$ & $906^{\mathrm{ab}}$ & $952^{\mathrm{a}}$ & 44 & * \\
\hline ADG (g/bird) & $30^{\mathrm{b}}$ & $25^{\mathrm{b}}$ & $35^{\mathrm{ab}}$ & $43^{\mathrm{ab}}$ & $45^{\mathrm{a}}$ & 2.1 & * \\
\hline \multicolumn{8}{|c|}{ Entire period } \\
\hline Total BWG (g/bird) & $1049^{b}$ & $1027^{b}$ & $1289^{a}$ & $1319^{a}$ & $1314^{\mathrm{a}}$ & 36 & * \\
\hline ADG (g/bird) & $25^{\mathrm{b}}$ & $25^{b}$ & $31^{\mathrm{a}}$ & $31^{\mathrm{a}}$ & $31^{\mathrm{a}}$ & 0.85 & $*$ \\
\hline \multicolumn{8}{|c|}{ DMCR } \\
\hline Starter & $2.1^{\mathrm{c}}$ & $1.7^{\mathrm{d}}$ & $1.5^{\mathrm{e}}$ & $2.2^{\mathrm{b}}$ & $2.5^{\mathrm{a}}$ & 0.02 & * \\
\hline Grower & $3.0^{\mathrm{b}}$ & $3.7^{\mathrm{a}}$ & $2.8^{\mathrm{b}}$ & $2.4^{\mathrm{c}}$ & $2.3^{\mathrm{d}}$ & 0.04 & $*$ \\
\hline Entire period & $2.6^{\mathrm{b}}$ & $2.7^{\mathrm{a}}$ & $2.26^{\mathrm{d}}$ & $2.34^{c}$ & $2.4^{\mathrm{c}}$ & 0.02 & * \\
\hline
\end{tabular}

${ }^{a b c} d m e a n s$ within the same row bearing different superscripts are significantly different $(P<0.05)$; $S E M=$ significant error of mean; $S L=$ significant level, $B W G=$ body weight gain, $A D G=$ average daily gain, $g=$ gram; $D M C R=$ feed conversion ratio

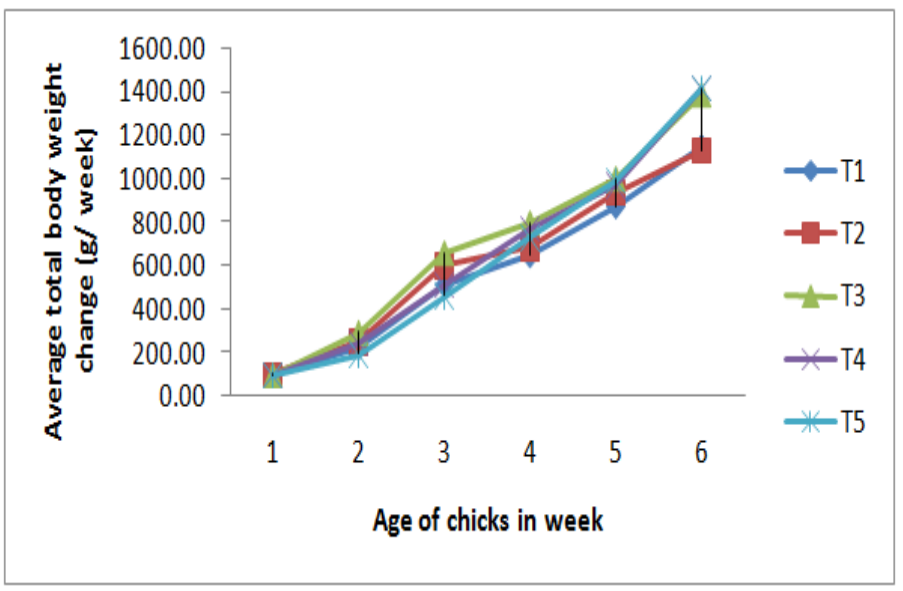

Figure 2: The average body weight change of the broilers fed different treatment diets over the treatment period.

\section{Carcass characteristics}

The carcass parameters and edible offal of broilers fed the experimental diets are shown in (Table 6). The slaughter weight and breast muscle for T5, T4 and T3 was higher $(\mathrm{P}<0.05)$ than those of $\mathrm{T} 1$ and $\mathrm{T} 2$ diets. The carcass weight for $\mathrm{T} 5$ and $\mathrm{T} 4$ was significantly higher than that of $\mathrm{T} 1$ and $\mathrm{T} 2$ but similar $(\mathrm{P}>0.05)$ with that of T3. The lowest $(\mathrm{P}>0.05)$ neck weight was for $\mathrm{T} 1$.
The wing weight for $\mathrm{T} 4$ was greater $(\mathrm{P}<0.05)$ than $\mathrm{T} 1, \mathrm{~T} 2$ and T3. There was no significant deference in the weight of thigh and dressing percentage among treatments. The drumstick weight for T3 was higher $(\mathrm{P}>0.05)$ than $\mathrm{T} 1$ while the values were similar $(\mathrm{P}>0.05)$ with other treatment diets. Skin weight for T5 was higher $(\mathrm{P}<0.05)$ than that of $\mathrm{T} 1$. The lowest $(\mathrm{P}<0.05)$ liver weight was for $\mathrm{T} 1$ while the highest $(\mathrm{P}<0.05)$ heart weight was for $\mathrm{T} 5$. 


\section{Agricultural Research \& Technology: Open Access Journal}

Table 6: The effect of substitution of cooked sweet potato tuber for maize on carcass traits and edible offal.

\begin{tabular}{|c|c|c|c|c|c|c|c|}
\hline Carcass weight (g) & Treatment & & & & & & \\
\hline & 1 & 2 & 3 & 4 & 5 & SEM & SL \\
\hline Slaughter & $1147^{\mathrm{b}}$ & $1127^{\mathrm{b}}$ & $1387^{\mathrm{a}}$ & $1417^{\mathrm{a}}$ & $1413^{\mathrm{a}}$ & 18 & $*$ \\
\hline Carcass & $623^{c}$ & $652^{\mathrm{bc}}$ & $709^{\text {ba }}$ & $743^{a}$ & $764^{\mathrm{a}}$ & 21 & $*$ \\
\hline Blood & $35^{b}$ & $40^{\mathrm{b}}$ & $46^{\mathrm{ab}}$ & $54^{\mathrm{a}}$ & $42^{\mathrm{ab}}$ & 4 & $*$ \\
\hline Neck & $28^{c}$ & $32^{\mathrm{a}}$ & $36^{\mathrm{a}}$ & $38^{\mathrm{a}}$ & $38^{\mathrm{a}}$ & 1 & $*$ \\
\hline Wing & $27^{c}$ & $34^{\mathrm{bc}}$ & $32^{\mathrm{bc}}$ & $42^{\mathrm{a}}$ & $38^{\mathrm{ab}}$ & 2 & $*$ \\
\hline Breast bone & $55^{c}$ & $75^{b}$ & $75^{b}$ & $75^{b}$ & $91^{\mathrm{a}}$ & 4 & $*$ \\
\hline Breast muscle & $130^{c}$ & $157^{\mathrm{b}}$ & $186^{\mathrm{a}}$ & $195^{\mathrm{a}}$ & $200^{\mathrm{a}}$ & 9 & $*$ \\
\hline Thigh & 123 & 143 & 140 & 143 & 136 & 5 & Ns \\
\hline Drumstick & $122^{\mathrm{b}}$ & $127^{\mathrm{ab}}$ & $135^{\mathrm{a}}$ & $130^{\mathrm{ab}}$ & $134^{\mathrm{ab}}$ & 4 & $*$ \\
\hline Abdominal bone & $89^{\mathrm{ab}}$ & $87^{\mathrm{ab}}$ & $73^{b}$ & $67^{\mathrm{b}}$ & $117^{\mathrm{a}}$ & 10 & $*$ \\
\hline Dressing percentage & 63.9 & 67.73 & 60.42 & 61.8 & 63.53 & 2.09 & Ns \\
\hline \multicolumn{8}{|c|}{ Edible offal (g) } \\
\hline Skin & $42^{\mathrm{b}}$ & $70^{\mathrm{ab}}$ & $66^{\mathrm{b}}$ & $70^{\mathrm{ab}}$ & $75^{a}$ & 2.81 & $*$ \\
\hline Gizzard & 31 & 31 & 29 & 27 & 25 & 1.87 & Ns \\
\hline Liver & $19^{b}$ & $29^{a}$ & $27^{\mathrm{a}}$ & $27^{a}$ & $28^{\mathrm{a}}$ & 1.66 & $*$ \\
\hline Heart & $5^{\mathrm{b}}$ & $6^{\mathrm{b}}$ & $6^{\mathrm{b}}$ & $5^{\mathrm{b}}$ & $7^{\mathrm{a}}$ & 0.22 & $*$ \\
\hline
\end{tabular}

abcmeans within the same row bearing different superscripts are significantly different $(P<0.05)$; $S E M=$ significant error of mean; $S L=$ significant level; CSPT= cooked sweet potato.

\section{Partial budget analysis}

Feed cost in the present study was evaluated based on the current market price of the ingredients. The results indicated that the total return, net return and marginal rate of return was highest for T5 diet (Table 7). The control treatment had the lowest return as compared to the ration containing PCSPTM. The result showed that, the cost of producing a bird with control diet was significantly higher than the rest of the treatments.

Table 7: Partial budget analysis of broiler chicks fed rations.

\begin{tabular}{|c|c|c|c|c|c|}
\hline \multirow{2}{*}{ Parameters } & \multicolumn{5}{|c|}{ Treatments } \\
\hline & T1 & T2 & T3 & T4 & T5 \\
\hline Purchase price/bird (Birr) & 6 & 6 & 6 & 6 & 6 \\
\hline $\begin{array}{l}\text { Feed consumed during entire } \\
\text { period (g/bird) }\end{array}$ & 2751 & 2811 & 2909.5 & 3076 & 3100 \\
\hline Feed cost(TVC, Birr/ bird) & 22.5 & 22.42 & 23.04 & 23.07 & 22.58 \\
\hline Selling price/bird (Birr) & 65.97 & 67.54 & 73.65 & 84.63 & 95.75 \\
\hline Total income (Birr/bird) & 59.97 & 61.54 & 67.65 & 78.63 & 89.75 \\
\hline Net income (Birr/bird) & 37.47 & 39.12 & 46.61 & 55.56 & 67.17 \\
\hline $\begin{array}{c}\text { Change in total variable cost } \\
(\Delta \mathrm{TVC})\end{array}$ & 0 & -0.08 & 0.54 & 0.57 & 0.08 \\
\hline Change in total income $(\Delta \mathrm{TI})$ & 0 & 1.57 & 7.68 & 18.66 & 29.78 \\
\hline Change in net income $(\Delta \mathrm{NI})$ & 0 & 1.65 & 7.14 & 18.09 & 29.7 \\
\hline MRR (\%/bird) & 0 & -20.62 & 13.22 & 31.73 & 371.25 \\
\hline
\end{tabular}

Maize; $\Delta \mathrm{NI}=$ change in net income; $\Delta \mathrm{TVC}=$ change in total variable cost; Birr = Ethiopian currency; $\mathrm{MRR}=$ marginal rate of return; $\mathrm{NI}=$ net income; TVC = total variable cost; $\Delta \mathrm{Tl}=$ change total income. 


\section{Discussion}

\section{Chemical composition of ingredients and experimental rations}

The crude protein value of PCSPTM obtained in this study was higher than the values (3.1\%) obtained earlier [9]. The total as value of PCSPTM obtained in this study was lower than the $4 \%$ obtained earlier [12], but higher than the $2.93 \%$ reported earlier [9].The CF content of PCSPTM in the current study was higher than $0.7 \%$ reported [20]. But it was lower than that (9.22\%) earlier reported [9]. Ether extract content of PCSPTM was higher than $0.71 \%$ [9] but lower than $2.5 \%$ earlier reported [12]. The variations in chemical composition could be attributed to differences in varieties, geographical areas and the conditions under which the plant was grown [21]. Generally, the CP, CF and EE content of PCSPTM was lower than those of the other ingredients which indicate that it is energy supplement [12]. The CF and EE content of the experimental diets in the present study slightly decreased with increasing level of PCSPTM since PCSPTM has lower CF than maize. Sweet potato tuber is lower in $\mathrm{CF}, \mathrm{CP}$ and EE content than maize [12]. The calcium and phosphorus content of the diet increased as the level of PCSPTM increased. This finding is in line with the suggestion that sweet potato tuber is a rich source of most minerals like calcium and micro-minerals [12].

\section{Dry matter and nutrient intake}

In the present study, feed intake was improved at higher level of supplementation, on 12\% (Table 4) and 16\% (Table 5) during starter phase and 15\% (Table 4) and 20\% (Table 5) during grower and entire phase. This is similar with earlier recommendation of $20 \%$ sweet potato inclusion for young birds [22] but slightly higher than $10 \%$ suggested as optimum level of utilization of sweet potato for broiler chicken [23]. As suggested earlier [24] low feed intake of broilers may be due to palatability problems associated with the nature of the diets which tend to be less digestible. Birds kept on T1 and T2 diet consumed higher amount of crude protein than the others during starter and grower phase due to high CP content of maize than that of PCSPTM. The CP intake of birds kept on T1 and T2 was higher than that of other treatments (Table 3-5) which could be due to the inverse relation between feed intake and nutrient intake (utilization). The absence of significant differences in ME intake of the birds fed the different treatment diets is due to similarity in ME contents of the treatment diets.

\section{Body weight gain and dry matter conversion ratio}

Chickens were fed diets consisting of 0 to $50 \%$ CSPT and it was found that there was increased body weight gain at higher level of CSPT [13] which is similar to the result in this study. During starter phase in T2 (4\%) and T3 (8\%) body weight gain was higher than in the rest of treatment diets. This result slightly agrees with the suggested $10 \%$ as optimum level of utilization of sweet potato by broiler chicken [23]. However, no significant differences were observed in earlier study when $0-40 \%$ sweet potato levels were used in the diets of broilers [13].
The result for dry matter feed conversion ratio (DMCR) at a substitution level of $16 \%$ (Table 5) PCSPTM with maize was higher than other treatments during starter stage. During grower and entire period, the poor feed utilization by T2 (5\%) PCSPTM birds may be due to the higher maize content of the diet, which could be attributed to its higher CF content. In contrast, DMCR decreased with increasing level of PCSPTM in the diet during growth and entire trial period. This result is in agreement with the earlier reports that the lower feed consumption and poorer efficiency of feed utilization led to an increase in feed conversion ratio $[5,25]$.

\section{Carcass weight and edible organ parts}

In the current study, carcass weight was higher in chickens under T4 (15\%) and T5 (20\%) which might be due to higher feed intake and body weight gain. A progressive increase in weights of total carcass and separate carcass components (drumsticks, breast and wings) were observed with increase in inclusion levels of PCSPTM. In the present study, progressive improvement in slaughter weight with increasing level of PCSPTM up to $20 \%$ was observed. In agreement with this result, high values of slaughter weight with increasing levels of orange flesh tuber meal in the diets of broiler chicks was also reported [22]. Dressing percentage was similar among all chickens kept on different treatments. Similar results of dressing percentage of the test diet containing $0-50 \%$ CSPT as a replacement for maize and that of the control group were reported [26] and this might be due to similarity in energy content of maize and sweet potato. In the current experiment gizzard weight was similar among all chickens kept on different treatments. This is in agreement with earlier finding that the organ weights of broilers did not present any significant difference among the treatment groups [27].

\section{Partial budget analysis}

According to the result of partial budget analysis of the present study, starter and grower rations containing PCSPTM had low feed cost/bird and returned a higher net profit than those fed the control diet. Results of feed cost agrees with what was obtained earlier $[9,13,25]$, who reported a linear decrease in the feed cost with increase in inclusion of sweet potato in broiler diet. Therefore, from biological point of view as well as partial budget analysis, T5 was found to be recommendable when compared to the others.

\section{Conclusion and Recommendations}

Substitution level of orange fleshed sweet potato tuber for maize by $12 \%$ and $16 \%$ at starter phase and $15 \%$ and $20 \%$ at grower phase have improved feed intake, body weight gain and carcass characteristics. The utilization CSPT by poultry producers should be encouraged because it is profitable by reducing production cost.Additional studies are necessary in order to determine the role of trypsin inhibitors in sweet potatoes on the bioavailability of nutrients and also the best processing methods to deactivate them. 


\section{Acknowledgement}

This research was fully supported by the research fund granted by the Ministry of Education transferred to Hawassa University for which the authors are highly grateful.

\section{References}

1. Mekonnen GR (2007) Characterization of smallholder poultry production and marketing system of dale, Wonsho and Loka Abaya Weredas of southern Ethiopia. Hawassa College of Agriculture, Hawassa University, Ethiopia, p. 95.

2. Amos TT (2006) Analysis of Backyard Poultry Production in Ondo state, Nigeria. International Journal of Poultry Science 5(3): 247-250.

3. Melesse A (2014) Significance of scavenging chicken production in the rural community of Africa for enhanced food security. World's Poultry Science Journal 70(3): 593-606.

4. FAO (2013) Total number of chickens for meat production in the world.

5. Ayuk EA (2004) Effect of sweet potato meal on the growth rate of broilers. Livestock Resource Rural Development 16(9): 73.

6. Afolayan SB, II Dafwang, Tegbe TSB, Sekoni A (2012) Response of broiler chickens fed on Maize-based diets substituted with graded levels of sweet potato meal. Asian Journal of Poultry Science 6: 15-22.

7. Agwunobi LN (1999) Performance of broiler chickens fed sweet potato meal (Ipomoea batatas L.) diets. Trop Anim Health and Prod 31(6): 383-389.

8. Ojewola GS, Olojede AO, Ehiri CG (2006) Evaluation of Livingston potato/Rizga (Plectranthuse sculentus N.Br) and Hausa potato (Solenostemonro tundifolius Poir) as energy sources for broiler chicken. Journal of Animal veterinary Advance 5(6): 472-477.

9. Afolayan SB (2010) Evaluation of sweet potato meal as a source of energy in the diets of chickens. Ph.D. Thesis, Department of Animal Science, Ahmadu Bello University, Zaria, Nigeria.

10. Dominguez PL (2010) Feeding sweet potato to monogastrics roots, tubers, plantains and banana in animal.

11. CGIAR (2001) Sweet potato CGIAR research areas of research.

12. Ravindran V, Blair R (1991) Feed resources for poultry production in Asia and the Pacific Region. Energy sources. World's Poultry Science Journal 47(3): 214-231.

13. Ayuk, EA, Essien A (2009) Growth and haematological response of broiler chicks fed graded levels of sweet potato (Ipomoea batata) meal as replacement for maize. International Journal of Poultry Science 8 (5): 485-488.

14. Gerpacio AL, Pascual FSd, Querubin LJ, Vergel de Dio AF, et al. (1978) Evaluation of tuber meals as energy sources. Sweet potato and cassava based rations for broilers. Philippine Agriculturalist 61(9-10): 395410.

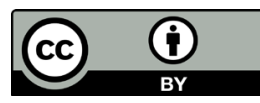

This work is licensed under Creative Commons Attribution 4.0 License DOI: 10.19080/ARTOAJ.2018.13.555895

15. NMA (2012) National Metrological Agency, Hawassa Branch Directorate. Hawassa, Southern Nations, Nationalities and Peoples Regional State, Ethiopia.

16. NRC (1994) National Research council, Nutrient requirements of poultry $9^{\text {th }}$ Revised Edition. National Academy press, Washington, USA.

17.Zanu HK, Asiedu P, Tampuori M, Abada M, Asante I, et al. (2012) Possibilities of using moringa (Moringa oleifera) leaf meal as a partial substitute for fishmeal in broiler chickens diets. Online Journal of Animal Feed Research 2(1): 70-75.

18. AOAC (1990) Official Methods of Analysis (15 ${ }^{\text {th }}$ edn). AOAC Inc Anc Arlington Virginia, USA, p.1298.

19. Wiseman J (1987) Feeding of Non-Ruminant Livestock. Butterworth and C.Ltd, pp. 370.

20. Noblet J, Fortuna H, Dupire C, Dubois S (1990) Valeurnutritionnelle de treizematieres premieres pourleporcencroissance. Teneursenenergie digestible metabolizableet nettle. Consequences du choix du systemeenergetique. Journees Rech Porcine En France 22: 175-184.

21. Ismaila Y (2014) Optimum level of utilization of cooked sweet potato meal (Ipomoea batatas LAM) in broiler chicken diets. An MSc Thesis presented to the School of Graduate Studies of Ahmadu Bello University, Zaria, Nigeria, p. 68.

22. Nguyen TT, Tran-phung TT, Pham NT, Dai P (2001) Processing, Storing Sweet Potato root by fermentation and using fermented feed to fatten pigs. Information of Science and Technologies on Animal Production 2: $167-169$

23. Berhann T and Wude T (2010) Effects of different levels of dried sweet potato (Ipomeabatatas) leaves inclusion in finishers ration on feed intake growth and carcass yield performance of Ross broiler chicks. Tropical Animal Health Production, 42(4): 687-695.

24. Banser JT, Fomunyam RT, Pone DK, Fai EN, Panigrahi S, et al. (2000) Effects of meals of sweet potato and cassava varieties formulated with soya meal or cotton seed on broiler production. Journal of Food Technology Africa 5(4): 115-119.

25. Maphosa T, Gunduza KT, Kusina J, Mutungamiri A (2003) Evaluation of sweet potato tuber (Ipomeabatatasl.) as a feed ingredient in broiler chicken diets. Livestock Research for Rural Development 15(1).

26. Tewe 00 (2001) Sweet potato Utilization in Poultry Diets. In: Symposium on Tropical Root Crops in a Developing Economy, Ofori, F. and S.K. Hahn (Eds.). International Society for Horticultural Science, USA, pp: 426-435.

27. Okorie KC, Nkwocha GA, Ndubuisi EC (2011) Implications of feeding varying dietary levels of cassava leaf meal on finisher broilers: performance, carcass haematological and serological profiles. Global Research Journal of Science 1: 58-66.

Your next submission with Juniper Publishers
will reach you the below assets
- Quality Editorial service
- Swift Peer Review
- Reprints availability
- E-prints Service
- Manuscript Podcast for convenient understanding
- Global attainment for your research
- Manuscript accessibility in different formats
( Pdf, E-pub, Full Text, Audio)
- Unceasing customer service
Track the below URL for one-step submission
https://juniperpublishers.com/online-submission.php

